by most academic pathologists, at any rate in London. $\mathrm{He}$ was a welcome and valuable recruit because. though only 36 years of age, he had already made his mark as an outstanding clinical pathologist, and in fact had that same year been appointed C.V.O. to reward his services to $\mathrm{King}$ George $\mathrm{V}$ in his serious illness. It was clear from the first that Whitby did not intend to be only a nominal member of our Association. He began to attend our meetings regularly. wrote papers and broadsheets for us, and often took part in our discussions. He was elected to the Council for the first time in 1934, and again after the war served for a second time as a Councillor from 1945-8. He was chosen as President-elect in 1950. and became our President from 1951-4.

It is scarcely necessary to say that within our Association Whitby was greatly respected and regarded by all with warm affection. Even those who did not know him personally formed such an opinion of him from his books and other writings, from his speeches, and general deportment at public functions. On the other hand, those of us who knew him more intimately and worked with him in the Association of Clinical Pathologists soon became aware of his exceptional ability, his wisdom, and the wide range of his knowledge, so that the confidence he had inspired immediately became deepened and strengthened by closer acquaintance. Moreover the honours and distinctions which were showered upon him later did not change the simplicity of his character or affect his loyalty to old friends. Wherever or whenever you met Lionel Whitby, and whoever you might be, you always met the same genial, straightforward, reliable person.

During the last four years in my tenure of office as chairman of the Council of the Association of Clinical Pathologists, I have frequently consulted with Lionel Whitby concerning the policy of our Association and its future development. It is no secret that he was strongly opposed to any attempt at the formation of a faculty or college of pathology at the present time, though he foresaw that something of this nature might be worth considering later. In the meantime he was quite definitely of the opinion that our immediate duty was to foster the development of clinical pathology and to make ourselves worthy of the status we have gained in the National Health Services. I do not know what his opinion would have been with regard to the proposed three categories of membership within the Association of Clinical Pathologists, but in one of my last conversations with him he expressed his whole-hearted approval of the policy of the Council in organizing short refresher courses for pathologists, and he thought the Association should exert its influence to ensure that consultant pathologists were adequately trained in all aspects of clinical pathology.

The Association of Clinical Pathologists has reason to be very grateful to Lionel Whitby. He gave of his best to all that he did for our Association, and we gained immeasurably from his personal influence and reputation. His outstanding contributions to clinical pathology have won him a secure place amongst the great men of our specialty. His unlimited capacity for friendship, his great social gifts. his humour, the merry twinkle in his eye, his boyish sense of fun-these are the qualities his friends will always treasure in their memories of Lionel Whitby.

Cuthrert Dukes.

\section{J. Stewart}

Matthew John Stewart. who died on November 7. 1956, was an Ayrshire man. born at Dalmellington on May 4, 1885. He graduated M.B., Ch.B. with

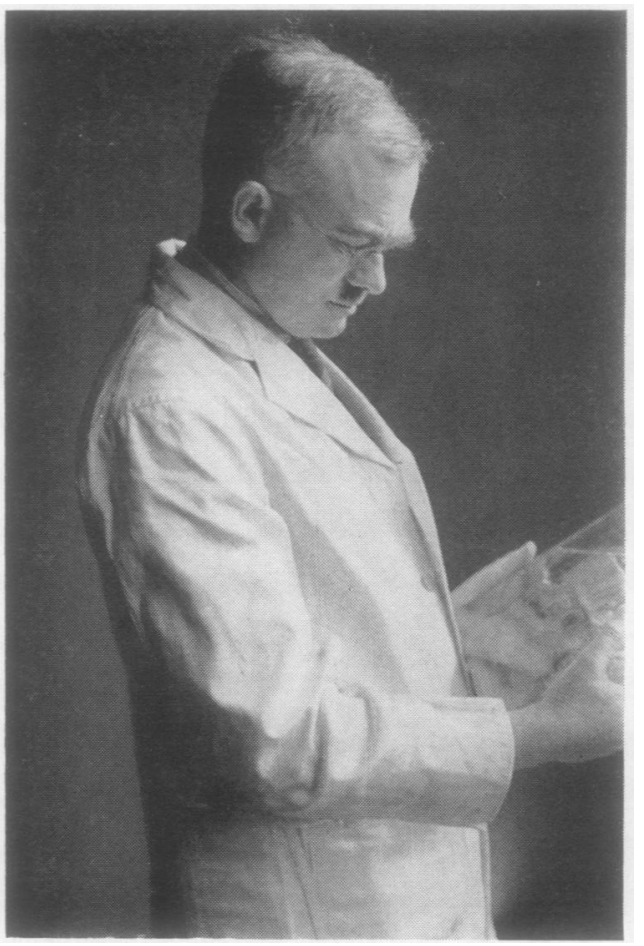

A photograph of Professor Stewart taken in his laboratory in 1932

honours at Glasgow University in 1907. For 33 years he was professor of pathology at Leeds, and for 33 years he was associated with the Journal of Pathology and Bacteriology, first as assistant editor and then, from 1934 to 1956 , as editor. Both as professor and as editor he left a great mark on the world of pathology. In his long tenure of the Leeds chair he built a school of pathology of the highest repute, and in his editorial work he laboured selflessly in creating and in maintaining the highest standards of medical journalism.

Stewart's first posts were in Glasgow with Samson Gemmell and John Brownlee, and he entered pathology under J. H. Teacher at the Royal Infirmary. It was not long, however. before he left Glasgow for 
Leeds, where he arrived in 1910 on being appointed clinical pathologist to the General Infirmary. In 1917, after war service at home and in France, Stewart succeeded Grünbaum in the chair of pathology. Then began a great era of expansion of the pathological services in Leeds. In his early days Stewart had to cope with all the pathology of the General Infirmary in two small back rooms. Here at one time he was fortunate enough to have as his assistant Dr. Clara Eglinton, whom most will know as that energetic, upright, and companionable person, Mrs. Stewart. They married in 1913. After a time certain rooms in the medical school, across the road from the Infirmary, were adapted to serve as routine and research laboratories. Then, some 20 years after Stewart's arrival in Leeds, the Algernon Firth Institute of Pathology was opened. Here, with Stewart as Director of the Institute, there were finally established four professorial departments, bacteriology, experimental pathology and cancer research, chemical pathology, and pathology, which embraced the routine laboratories in the Infirmary for morbid anatomy and haematology and was embellished by the huge museum beneath the roof. All this emerged from Stewart's vision, hard work, and influence. He served the Leeds school and University splendidly, not only in this way, but also as academic sub-dean and dean for many years, as pro-vice-chancellor for a spell, as representative on the General Medical Council for eight years, and as an experienced counsellor and committee member.

Throughout all the period of expansion in Leeds, Stewart was gathering a great reputation as a morbid anatomist, as a teacher and examiner, and as an original worker. He wrote wisely and authoritatively on diseases of the stomach, on pneumoconiosis, on giant-cell tumours of bone, on gynaecological pathology, and on many other matters that gave scope to his acute powers of observation with the microscope or at the necropsy table. Many who visited him with a problematical slide will recall the uncanny efficiency with which he utilized his antiquated brass monocular microscope with its mirror tilted at the usually leaden Leeds sky.

In later years Stewart's heavy commitments with national and local academic committees and his meticulous editing of a rapidly growing journal took up much of his time, but he never missed a lecture or a teaching session in the post-mortem room except under the greatest pressure, and he always responded immediately to a call for professional help from one of his staff or from a clinical colleague. Indeed, his willingness to help was not restricted to the circle of his immediate associates. He was the most approachable of men and was always ready to give generous assistance, whether it was a matter of histological opinion, of advice on the preparation of a manuscript, or of wise counsel about a vacant post or some proposed course of action.

On a recent public occasion Matt Stewart was portrayed as having a genius for friendship. Indeed, he was one of those happy persons with whom the stage of mere acquaintance hardly existed. His genius for friendship embraced the capacity for taking a real and lively interest in everyone he met and a facility for remembering personal details and for establishing a sense of easy mutual confidence. It was characteristic of Matt at any social or scientific gathering to make a special point of introducing his most junior staff to as many people as possible with the heart-stirring phrase, "This is my colleague, Dr. - -."

Stewart was a staunch conservative; but his own achievements and the way in which he welcomed new work in pathology indicate that he was no narrow reactionary. He was a great judge of quality and, as befitted his Scottish ancestry, of value. What may have appeared at times to be a tendency to parsimony in public affairs was dictated by conscience and a high sense of responsibility and was offset by great personal generosity, which all who experienced the hospitality of his home well knew.

He was devoted to the Pathological Society of Great Britain and Ireland, in whose history he played so large a role. If for a time he may have seemed unsympathetic to the younger Association of Clinical Pathologists it was largely because he disapproved of blending medical politics with scientific activity. $\mathrm{He}$ was himself at heart a clinical pathologist. He had been so appointed in the far-off days of 1910 . When in 1948 he was elected an honorary member, he gave the Association of Clinical Pathologists his warm support, participating in some of its meetings, sometimes in the chair, and entertaining the Association in magnificent style when it met in Leeds in July, 1950.

Stewart was honoured by the University of Glasgow in 1938 when he was awarded the degree of LL.D. In 1951 he received the honorary degree of M.D. at the University of Melbourne, and in the same year he was appointed C.B.E.

When Matt left Leeds on his retirement, we knew that we should no more encounter his energetic, shortish figure dashing up the hill to the University for some meeting, with a bulging brief-case or a sheaf of papers in his hand and a battered hat crammed on to his large globular head. Nor would we again watch him "make post-mortems in the forenoon" with the acuity of observation that generally led to an anatomical summary of a dozen or more unsuspected lesions. But for some years after, his genial presence at meetings, his bushy eyebrows above the steel-rimmed glasses, his scarcely legible letters and post-cards, and his sustained personal interest in everyone's doings continued to delight his numerous friends both at home and abroad. But, in the words of his compatriot whom he loved to quote. "Nae man can tether time or tide," and Matt is with us no longer.

He has his memorials in the files of the Journal of Pathology and Bacteriology, and in Leeds there are the Institute of Pathology, with his bas-relief in the entrance, and the well-endowed Matthew Stewart Lectureship. Far and wide he will be gratefully remembered for his services to pathology and for his engaging personal qualities.

D. H. Collins. 